Ingrid Vilsmeier

\title{
Tatsachenkontrolle und Beweisführung im EU- Kartellrecht auf dem Prüfstand der EMRK
}

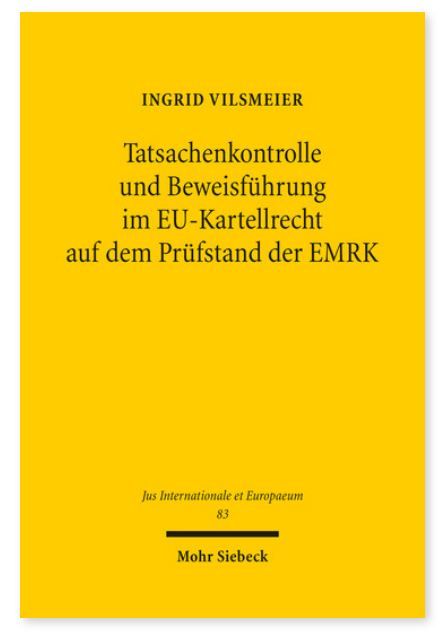

2013. XV, 269 Seiten. JusIntEu 83

ISBN 978-3-16-152853-8

DOI 10.1628/978-3-16-152853-8

eBook PDF 74,00€

ISBN 978-3-16-152791-3

fadengeheftete Broschur 74,00€
Die Geltung strafverfahrensrechtlicher Garantien für das EU-Kartellverfahren ist seit langem Gegenstand der juristischen Diskussion. Dabei wurde gerade in den letzten Jahren vermehrt kritisiert, dass das EU-Kartellverfahren hinter den strafverfahrensrechtlichen Anforderungen der Europäischen Menschenrechtskonvention (EMRK) zurückbleibe. Durch den im Vertrag von Lissabon vorgesehenen Beitritt der Union zur EMRK und die damit bevorstehende Grundrechtskontrolle durch den Europäischen Gerichtshof für Menschenrechte hat diese Thematik noch einmal an Brisanz gewonnen. Ausgehend von der Qualifizierung des EU-Kartellverfahrens als Strafverfahren im Sinn der EMRK untersucht die Autorin die Vereinbarkeit der unionsgerichtlichen Kontrolle von Sachverhaltsfeststellung und Beweisführung der Kommission im EUKartellrecht mit den Vorgaben der EMRK.

Ingrid Vilsmeier Geboren 1981; Studium der Rechtswissenschaften in Passau, München und London; Referendariat im OLGBezirk München; wissenschaftliche Mitarbeiterin an der LMU München; Fachsprachendozentin an der Université PanthéonAssas Paris; seit 2011 im bayerischen Justizdienst tätig.

Jetzt bestellen:

https://mohrsiebeck.com/buch/tatsachenkontrolle-und-beweisfuehrung-im-eu-kartellrecht-auf-dem-pruefstand-der-emrk9783161528538?no_cache=1

order@mohrsiebeck.com

Telefon: +49 (0)7071-923-17

Telefax: +49 (0)7071-51104 